Nevșehir Bilim ve Teknoloji Dergisi TARGíd Özel Sayı 372-384 2016

DOI: 10.17100/nevbiltek.211028

URL: http://dx.doi.org/10.17100/nevbiltek.211028

\title{
Tarım Arazilerindeki Yapılaşma Baskısının Azaltılmasında Köy Gelişme Alanı ve İmar Uygulamaları: İç Anadolu Bölgesi Örneği
}

\author{
Aslı Akci ${ }^{*}$, Mustafa Kürşat Demirel, Havva Şen Becu \\ Gıda, Tarım ve Hayvancılık Bakanlığı, Tarım Reformu Gen. Müd., Ankara, Türkiye
}

Öz

Tarım arazilerinin amacına uygun biçimde kullanılması gereklidir. Verimli tarım arazilerinin yapılaşmaya açılması, sınırlı olan bu kaynakları tüketmeye sebep olmaktadır. Tarımsal araziler ihtiyaç duyulduğunda tarım dışı amaçlar için kullanılabilmektedir, fakat tarım dışı amaçla kullanılan ve yapılaşmaya açılan arazilerin, tekrar tarıma kazandırılması çoğu kez olanaksızdır.Verimli tarım topraklarının iskana açılma problemi daha çok kentsel alanlarda yaşanmaktadır. Ancak bu problemin başka bir türü ise kırsal alanlarda, çiftçilerin konut ihtiyaçları için, kendi tarım arazisinde bina yapmasıyla ortaya çıkmaktadır.

Köy gelişme alanı ve imar uygulaması; tarım arazilerindeki yapılaşma baskısının azaltılması ve planlı kırsal yerleşim birimlerinin oluşturulması amacıyla hazine arazilerinde gerçekleştirilen bir çalışmadır. Bu uygulamayla köyün genişleme alanı belirlenmekte, köyün planlı olarak gelişmesi sağlanmakta ve böylece köy sakinlerinin ihtiyaç duyduğu konutu yapabileceği tarımsal niteliği düşük alanlarda arsa üretilerek, tarımsal niteliği yüksek alanlardaki yapılaşma baskısı azaltılmaktadır. Türkiye genelinde bu uygulamanın yaygınlaştırılması, kırsal alandaki tarım arazilerinin korunmasına önemli katkılar sağlayacaktır. Bu çalışmada, köy gelişme alanı ve imar uygulamalarının tarımsal arazilerdeki yapılaşma baskısının azaltılmasındaki etkileri örnekler verilerek açıklanmaktadır.

Anahtar Kelimeler: Arazi toplulaştırma, Köy gelişme alanı, Yapılaşma.

\section{Village Development Areas And The Application Development For Reducing Of Construction On Agricultural Land: The Case of Central Anatolia Region}

\begin{abstract}
Agricultural land should be used suitable of properties. If productive agricultural lands is used for housing needs, limited productive agricultural land will lead to reduce. Agricultural land can be used other uses when it is necessary but land used other uses isn't changed in agricultural land. The problem of efficient deployment of agricultural land to resettle in urban areas more experienced. However, if it is another type of problem in rural areas, farmers for housing needs, taking an emerging building their farming land. Village development areas and application development is a work for reducing the pressure on agricultural land and creating planned residential units. With applied to the village development area, development area of village is selected, so villages develop regularly and where the high areas of the agricultural nature of the construction pressure is reduced. This system in Türkiye, will contribute to the conservation of agricultural land in the rural areas. In this case choosing village development areas and reconstruction works will be explained by giving examples on the effect of protect of agricultural land.
\end{abstract}

Keywords : Land consolidation, Village development area, Construction

* e-mail: aslialagoz@gmail.com 


\section{Giriş}

İnsan yaşamı için gerekli olan besin maddeleri geçmişte olduğu gibi günümüzde de tarımsal uğraşılar sonucunda elde edilebilmektedir. Bu maddelerin üretiminde yararlanılan temel kaynaklardan biri ve en önemlisi topraktır. Çok uzun sürede oluşan ama yanlış kullanılma sonucu kolayca bozulabilen ve bozulduktan sonra da geriye kazanılması ya da eski durumuna getirilmesi binlerce yıl süren değerli bir varlıktır. Toprak, insan yaşamı için gerekli fakat kısıtlı bir kaynaktır [1].

Dünya yüzeyinin yaklaşık 13 milyar hektarı karalarla kaplı olup, bunun yüzde 37’sine tekabül eden yaklaşık 5 milyar hektarını tarım arazileri oluşturmaktadır. Söz konusu tarım arazisi varlığının kullanım şekline göre dağılımına bakıldığında; yaklaşık 1,5 milyar hektar alanda tarla bitkileri yetiştiriciliğinin yapıldığı, yine 1,5 milyar hektarda çok yıllık bitkilerin dikili bulunduğu görülmektedir. Geriye kalan 2 milyar hektar alan ise çayır ve mera şeklinde değerlendirilmektedir [2].

Yeryüzündeki araziler, kullanma kabiliyet sınıflarına göre sekiz sınıfa ayrılmaktadır. Bu sınıflamada I., II., III. ve IV. sınıf araziler sürülerek tarım yapmaya elverişli arazilerdir. V., VI., VII. ve VIII. sınıf arazilerde sürüm yapılması doğru değildir (Tablo 1). Ancak pahalı toprak ve su muhafaza önlemleri alınarak bazı bitkiler yetiştirilebilir.

Tablo 1. Arazi yetenek sinifları [6]

\begin{tabular}{|c|c|c|c|}
\hline $\begin{array}{c}\text { Tarıma Uygun } \\
\text { Olup/Olmama } \\
\text { Durumu }\end{array}$ & Kullanım Biçimi & $\begin{array}{l}\text { Arazi Yetenek } \\
\text { Sinıfı }\end{array}$ & Özellikleri \\
\hline \multirow[t]{7}{*}{ Tarıma Uygun Araziler } & \multirow[t]{3}{*}{$\begin{array}{l}\text { İşlemeli Tarıma } \\
\text { Uygun Araziler }\end{array}$} & $\mathbf{I}$ & $\begin{array}{l}\text { Düz veya düze yakın, derin, verimli, kolayca işlenebilen } \\
\text { araziler }\end{array}$ \\
\hline & & II & Hafif eğimli, verimli, kolayca işlenebilen araziler \\
\hline & & III & $\begin{array}{l}\text { Orta derece eğimli, verimli, orta derece işlenebilen } \\
\text { araziler }\end{array}$ \\
\hline & $\begin{array}{c}\text { Kısıtli İşlemeye } \\
\text { Uygun Olan Araziler }\end{array}$ & IV & Fazla derecede eğimli, kısıtlı olarak işlenebilen araziler \\
\hline & \multirow[t]{4}{*}{$\begin{array}{l}\text { İşlemeye Uygun } \\
\text { Olmayan Araziler }\end{array}$} & $\mathbf{V}$ & $\begin{array}{l}\text { Çayır ve orman gibi uzun ömürlü bitki yetişmesine } \\
\text { olanak veren araziler }\end{array}$ \\
\hline & & VI & $\begin{array}{l}\text { Fazla eğimli ve şiddetli erozyona maruz kalabilen } \\
\text { araziler }\end{array}$ \\
\hline & & VII & $\begin{array}{l}\text { Fazla eğimli, taşlı yapıya sahip, bataklık veya diğer } \\
\text { elverişsiz toprakları da içeren araziler }\end{array}$ \\
\hline $\begin{array}{l}\text { Tarıma Uygun Olmayan } \\
\text { Araziler }\end{array}$ & & VIII & $\begin{array}{c}\text { Bataklık, çöl, çok derin oyuntuları içeren topraklar, } \\
\text { dağlık ve taşlık araziler }\end{array}$ \\
\hline
\end{tabular}

Toprağın yetenek sınıflarına uygun şekilde kullanılması gereklidir. Fakat ülkemizde kârlılık kriteri gözetilerek, diğer sektörlerin (sanayi, konut, altyapı, enerji, turizm) ihtiyaç duyduğu yerleşim yeri ya da toprak kullanımlarında, toprak yetenek sınıfları gözetilmeden hareket edildiği gözlenmektedir [1]. Tarım arazilerinin tarım dışı kullanımları sonucunda yıllar itibariyle ekilebilir arazilerde azalma görülmektedir (Tablo 2). Türkiye'deki tarım toprakları incelendiğinde nadasa bırakılan arazilerde yıllar itibariyle azalma görülmesine rağmen ekilen araziler her yıl azalmaktadır. Bu durumun en önemli nedeni ekilebilir ve verimli bu arazilerin tarım dışı amaçlı olarak yapılaşmaya açılmasıdır. Çayır ve mera arazilerinde herhangi bir azalma olmamasının nedeni ise bu alanların Mera Kanunu ile korunuyor olmasıdır. Bu kanunla çayır ve mera arazilerine yapılaşma yasağı getirilmiştir. 
Akci A., Demirel MK., Şen Becu H.

Tablo 2. Türkiye’de tarım alanları [3]

\begin{tabular}{|c|c|c|c|c|c|c|c|}
\hline \multirow{3}{*}{ Yil } & \multirow{3}{*}{$\begin{array}{r}\text { Toplam } \\
\text { tarım alanı }\end{array}$} & & & \multicolumn{4}{|r|}{ Bin Hektar } \\
\hline & & \multicolumn{2}{|c|}{$\begin{array}{l}\text { Tahıllar ve diğer } \\
\text { bitkisel ürünlerin alanı }\end{array}$} & \multirow{2}{*}{$\begin{array}{r}\text { Sebze } \\
\text { bahçeleri } \\
\text { alanı }\end{array}$} & \multirow{2}{*}{$\begin{array}{r}\text { Süs bitkileri } \\
\text { alanı }\end{array}$} & \multirow{2}{*}{$\begin{array}{r}\text { Meyveler, } \\
\text { içecek ve } \\
\text { baharat } \\
\text { bitkileri alanı }\end{array}$} & \multirow{2}{*}{$\begin{array}{r}\text { Çayır ve } \\
\text { mera arazis }\end{array}$} \\
\hline & & Ekilen alan & Nadas & & & & \\
\hline 2010 & 39012 & 16333 & 4249 & 802 & - & 3011 & 14617 \\
\hline 2011 & 38231 & 15692 & 4017 & 810 & 4 & 3091 & 14617 \\
\hline 2012 & 38399 & 15463 & 4286 & 827 & 5 & 3201 & 14617 \\
\hline 2013 & 38423 & 15613 & 4148 & 808 & 5 & 3232 & 14617 \\
\hline 2014 & 38560 & 15789 & 4108 & 804 & 5 & 3238 & 14617 \\
\hline
\end{tabular}

Türkiye’de tarımsal üretim amaçlı kullanılan arazilerin yaklaşık 21,4 milyon hektarı işlenen tarım arazisi olup, 3 milyon hektar alan meyve bahçeleri ve zeytinliklerle kaplıdır. Toplam çayır-mera alanı ise yaklaşık 14,6 milyon hektardır. Bu veriler dikkate alındığında, 2011 yılı itibarıyla tarımsal amaçlı olarak kullanılan toplam arazi varlığının 38,2 milyon hektar olduğu anlaşılmaktadır. Öte yandan, kullanım şekli itibarıyla, miktarı yıldan yıla değişmekle birlikte, işlenen tarım alanlarının yüzde 1822’sini teşkil eden 4-5 milyon hektar tarım arazisi de nadasa bırakılmaktadır [2].

\subsection{Tarım Arazilerinde Yapılaşma Baskıları}

Arazilerin potansiyellerine uygun şekilde değerlendirilmesi doğal kaynaklarının sürdürülebilir kullanımında temel esastır. Ülkemizde tarım arazilerinin en temel sorunları erozyon ve tarım arazilerinin tarımsal amaçlar dışında kullanılmasıdır [4].

Toprak ve su kaynaklarının korunması ve geliştirilmesi için yapılacak çalışmalarda göz önüne alınması gereken iki husus vardır. Bunlardan birincisi toprağın üretim gücünün korunması, toprağın dengesini bozan etmenlerin kontrol altına alınması; diğeri ise tarımsal amaçlar dışındaki kullanımlar için uygun yer seçimidir [5].

Tarım arazilerinin amaç dışı kullanımının en yaygın görüldüğü alanlar sırasıyla sanayi, konutkentleşme, turizm ve madencilik ile ulaştırma amaçlı kamu yatırımları şeklinde sıralanmaktadır. Türkiye’de 1989-2010 döneminde toplam 827 bin hektar tarım arazisinin tarım dışı faaliyet alanlarında kullanımına izin verilmiştir. Tarım arazilerinin tarım dışı kullanımına yönelik istatistikler, mülga Tarım ve Köyişleri Bakanlığı tarafından başlangıçta ülke ölçeğinde "genel toplam” olarak kayıt altına alınırken, 2010 yılından itibaren sektörel bazda kayıt altına alınmaya başlanmıştır. Bu kapsamda, GTHB 2011 yılı kayıtlarına göre, tarım arazilerinin tarım dışı kullanımına yönelik sektörel bazlı değerler, konut amaçlı 12,4 bin hektar, sanayi amaçlı 22,4 bin hektar, turizm amaçlı 1,2 bin hektar, madencilik amaçlı 7,9 bin hektar ve ulaştırma amaçlı 650 hektar olmak üzere toplam 44,5 bin hektar olarak gerçekleşmiştir [6].

\subsubsection{Tarım dışı Faaliyetlerin (İskan, Turizm, Sanayi vd.) Olumsuz Etkileri}

Tarım arazilerinin, kentleşme, sanayi, turizm gibi tarım dışı amaçlarla kullanımı sonucu öncelikle tarım toprakları geri dönüşümü olmayacak biçimde yok olma tehlikesi ile karşı karşıya bulunmaktadır. Ülkemizde tarım arazilerinin tarım dışı kullanımı devam ettiği sürece sınırlı miktardaki verimli tarım arazileri hızla azalacaktır. Bu durum, aynı zamanda tarım arazilerine yönelik daha önce büyük maliyetlerle yapılmış olan sulama ve tarımsal altyapı gibi yatırımların atıl kalmasına da neden 
olacaktır. Diğer taraftan, tarım arazilerinin nüfusa bağlı olarak giderek azalması nedeniyle gelecekte yaşanması muhtemel açlık tehlikesi, yine azalan tarım arazisi neticesinde biyolojik çeşitlilik üzerindeki olası olumsuz etkileri ve tarım arazisi ihtiyacının çayır ve mera arazilerinden karşılanarak ekolojik dengenin bozulması gibi hususlar, tarım arazilerinin korunması ve etkin kullanımının sağlanmasının ne kadar gerekli ve önemli olduğunu gözler önüne sermektedir [6].

Tarım dışı arazi kullanımlarında kısa vadede rant veya kazanç oranı yüksek olabilmektedir. Buna ülkede izlenen tarım politikası ve özellikle de tarımsal fiyat ve destekleme politikasının olumsuz etkileri de eklenince tarım topraklarının elden çıkması hız kazanmaktadır. Böylece büyük yerleşim yerleri (şehirler) ve kıyılarda, yetenek sınıfları öncelikle tarımsal faaliyetlere daha uygun verimli topraklar, yeni sanayi ve yeni konut alanları kurma, kamu alt yapı tesisleri ve turizm yatırımları yapma ve diğer çeşitli amaçlarla gelecekteki ihtiyaçlar gözetilmeden tarım dışına çıkarılmaktadır [1].

\subsubsection{Sanayi Alanları}

Verim gücü düşük bir toprakta, kolay ve başarılı tarım yapılamaz, fakat sanayi kuruluşları hiçbir verim düşüklüğü göstermeden bu verimsiz topraklar üzerinde kurulabilir ve faaliyetini devam ettirebilirler. Böylece sanayi yapılarının verimli tarım toprakları üzerinde değil de verimsiz ya da daha az verimli tarım toprakları üzerinde kurulması ile verimli tarım toprakları üzerinde tarımsal faaliyetten elde edilen gelir de, ülke ekonomisinde sanayi gelirleri üzerine bir artı değer olarak kayıt edilmiş olacaktır [1].

\subsubsection{Turistik Tesis Alanları}

Verimli tarım topraklarııın amaç dışı kullanımının bir başka şekli; yazlık, ikinci konut, turistik siteler, kamu kuruluşlarının sosyal-eğitim ve dinlenme tesisleri olarak özellikle kıyı kesimindeki alanların işgal edilmesidir [1].

\subsubsection{Konut Alanları}

Verimli tarım topraklarının kentleşme eyleminde kullanılıyor olması, elden çıkması, kentleşme olgusu, yerleşimlerin düzenlenmelerinde çevre faktörlerinin (güneşlenme durumu, gün 1şı̆ğ, hakim rüzgar yönü, hava akımları, çevre yeşillikleri, yer altı suyu seviyeleri, jeofiziksel özellik vd.) yeterince değerlendirilememesi ile çarpık kentleşme olgusu kendini daha belirginleştirmektedir [7]. Bunun sonucu olarak şehirlerde plansız ve kontrolsüz yapılaşmalar olmuş ve şehir çevrelerindeki tarım arazilerine doğru yayılmalar başlamıştır. Şehirlerin etrafındaki bağ, bahçe ve tarla arazileri büyük bir hızla yeni yerleşim bölgelerine dönüşmüştür. Yerleşim alanları civarındaki tarım arazilerinin arsaya dönüşmesi ile değerinde meydana gelen ani artış, bu arazilerin tarımsal niteliğinin korunmasını güçleştirmektedir. Kentlerin gelişme yönleri, arsa taleplerinin belirlenmesinden önce saptanarak gerekli planlamalar yapılmadığı için tarım arazileri, emlak komisyonlarının istekleri yönünde ve bu değer artışına bağlı olarak kolaylıkla tarım dışı kullanıma kaymaktadır [8].

Kırsaldaki insanların konut ihtiyaçlarını kendi tarım arazisinde çözümlemeye çalışması sonucunda; dağınık yerleşimler oluşmaktadır.

Plansız bu yerleşmelerin sonucunda ise; hanelerin yol, su, kanalizasyon ve elektrik gibi temel teknik altyapı hizmetleri artmakla birlikte, kırsal kesim için yatırım maliyetleri de oldukça artmaktadır. 
$\mathrm{Bu}$ hizmetler ve yolların neredeyse her konuta ayrıca ulaştırılması gerekmiştir. Öte yandan kırsal plan eksikliğinden dolayı, taşınmaz sahipleri arazilerini sürekli parselleyerek altyapısız olarak kullanmakta ve sonuçta kent merkezlerinde görülebilen yapı yoğunlukları oluşmaktadır [9]. Bu duruma bir örnek Harran Ovasıdır; tarım alanlarında konut ve sanayi olmak üzere iki alanda amaç dışı kullanım olduğu görülmüştür. Toplamda 4224 adet yapılaşmanın 11651 dekar tarım alanını işgal ettiği tespit edilmiştir. Tarım alanlarında amaç dışı kullanım bu hızla devam ederse, Harran Ovası yerini büyük bir Harran köyüne bırakacaktır [10]. Harran Ovası'nda tarım arazileri üzerindeki yapılaşma aşağıdaki paftada görünmektedir.

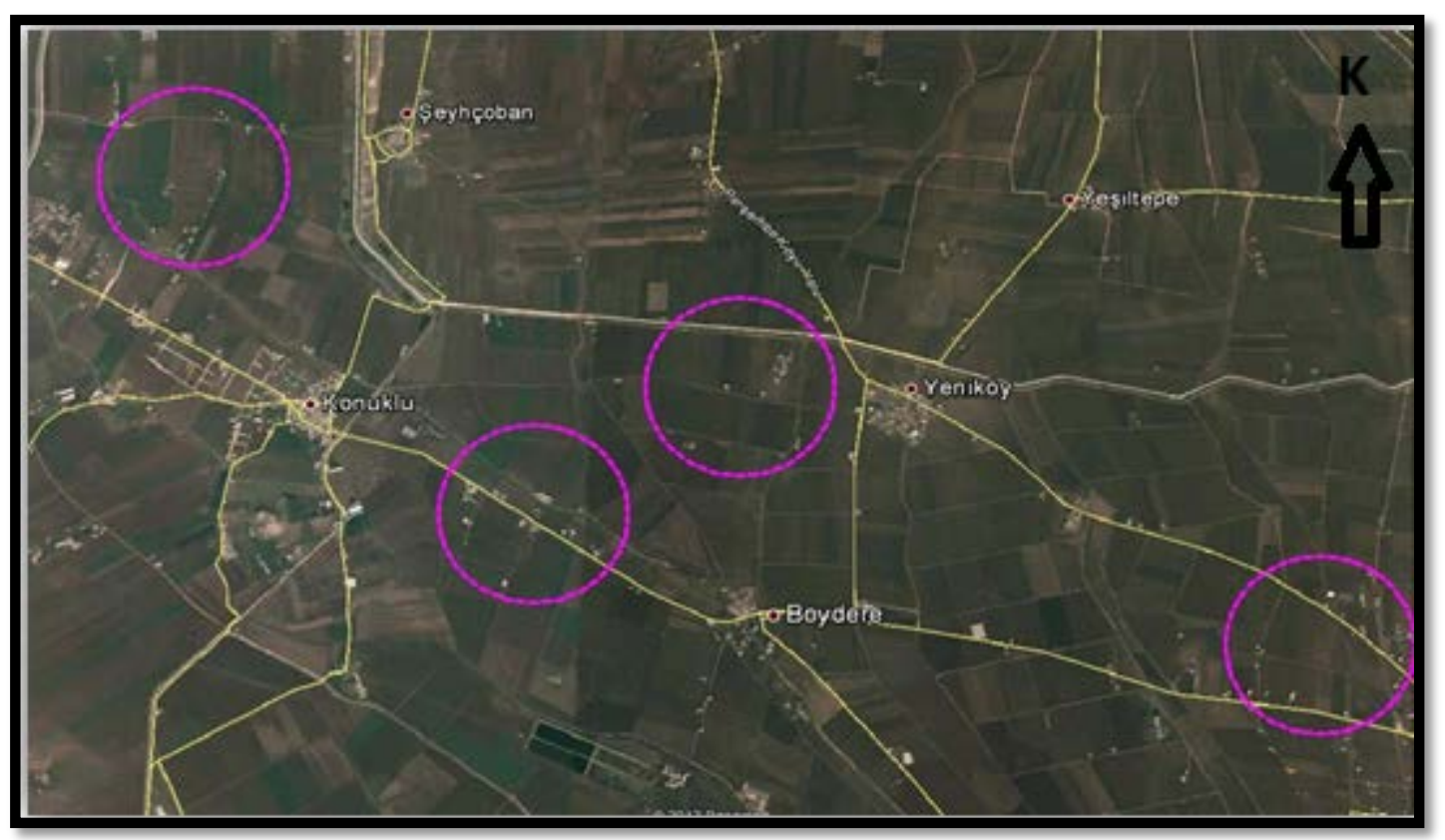

Şekil 1. Harran Ovasında tarım arazileri üzerindeki yapılaşmalar [9]

\section{Materyal ve Metot: Köy Gelişme Alanı ve İmar Uygulaması}

Kırsal alandaki konut sorununun çözümü için kullanılan bir yöntem olan köy gelişme alanı uygulaması uygulanan projelerden örnekler verilerek irdelenmekte ve tarım arazileri üzerindeki yapılaşma baskısının azaltılmasına yönelik sonuçları ortaya çıkarılmaktadır.

Köy gelişme alanı uygulamasıyla; mevcut köylerde düzenli yapılaşmayı sağlamak, tarım arazilerine olan işgallerin önlenmesini sağlamak, geleceğe yönelik olarak arsa üreterek vatandaşların konut, zirai yapı-tesis ve sosyal-kültürel tesis ihtiyaçlarını karşılamak amaçlanmaktadır. Köy gelişme alanı olarak ayrılan hazine arazisinde iskan imkanı sunularak kırsaldaki insanın konut ihtiyacı tarım arazilerinin bölünmesine gerek duyulmadan çözümlenmiş olmaktadır.

Köy gelişme alanı tespit çalışmaları öncelikle köyün mevcuttaki ve 20 yıl sonrasındaki konut, yeşil alan, sosyal, kültürel ve eğitim donatı ihtiyacının hesaplanmasıyla başlamakta, tarımsal niteliği olmayan hazine, tapulama harici alan veya vasıf değişikliği yapılarak mera arazisi tespit edilmekte, alanın tarımsal, jeolojik ve topoğrafik yönden yerleşime uygunluğu incelenmekte ve bu alan üzerinde imar planı hazırlayıp uygulayarak plansız ve çarpık yerleşimlerin ortaya çıkması önlenmektedir. 


\section{Bulgular: Uygulama Örnekleri}

Köy gelişme alanı uygulamalarından örnekler aşağıda verilmektedir. Her bir projeyle ilgili olarak ihtiyaç analizi, gelişme alanı tespiti, imar uygulaması ve projenin köydeki tarımsal araziye etkileri incelenmektedir. Uygulanan köy gelişme alanı projeleriyle;

- Nüfus artışı gösteren bir yerleşim yerinin gelişme ve genişlemesinin planlı şekilde yönlendirilmesi,

- Doğal afetler yönünden sakıncalı olan mevcut yerleşim yerinin genişlemesinin durdurularak yapılaşmanın doğal afetler açısından daha uygun bir alana yönlendirilmesi,

- Mevcut yerleşim yeri sit alanı ilan edilen köyün konut ve sosyal-kültürel tesisleri için yerleşime uygun alana taşınması amaçlanmaktadır.

Aşağıdaki haritada köy gelişme alanı uygulamalarından seçilen örneklerin bulunduğu iller gösterilmektedir.

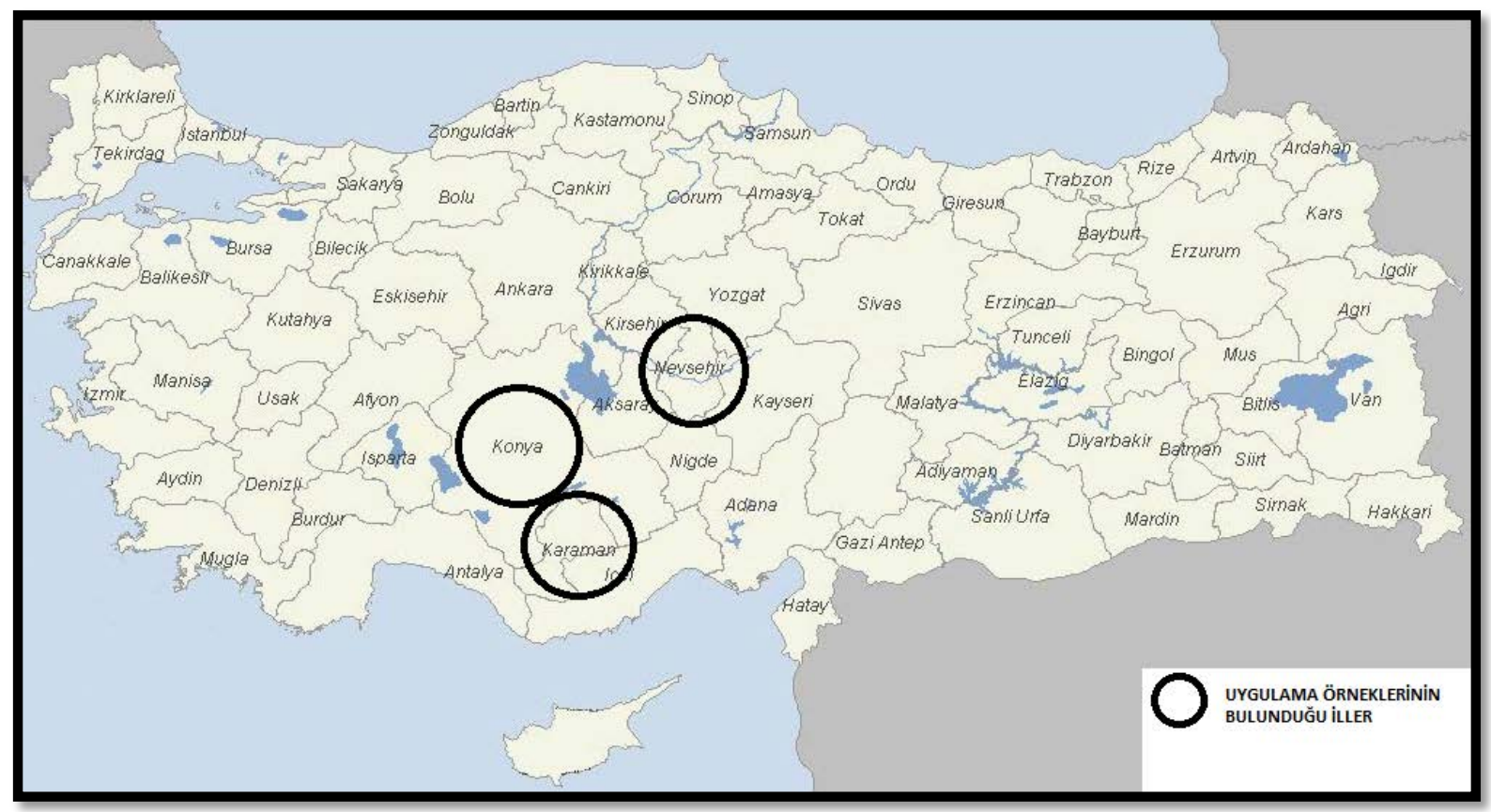

Şekil 2. Uygulama örneklerinin bulunduğu iller

Birincisi; Konya İli Karatay İlçesi’ne bağlı Katrancı Köyü olup; köyün 2007 nüfusu 167 ve 2010 yılı nüfusu 205 kişidir. Köyün ile ve ilçeye uzaklığı 70km’dir. Köyün temel geçim kaynakları tarım ve hayvancılıktır. Mevcut yerleşim yerinin tamamı ovada bulunmakta olup; Katrancı köyünde eğitim, sosyo-kültürel ve kamu tesisi bulunmamakta olup; köyün camisi mevcuttur. Köyde yapılan köy gelişme alanı tespit çalışmalarında köy konağı, kooperatif tesisi, spor sahası, halk eğitim merkezi, ticari tesis ve hayvan pazarına ihtiyacı belirlenmiştir [12].

İkincisi; Nevşehir İli Derinkuyu İlçesi’ne bağlı Kuyulutatlar Köyü olup; köyün 2009 nüfusu 1383 ve 2012 yılı nüfusu 1253 kişidir. Köyün ile uzaklığı 47 km ve ilçeye uzaklığ1 16 km’dir. Köyün temel geçim kaynakları tarım ve hayvancılıktır. Mevcut yerleşim yerinin tamamı ovada bulunmakta olup; köyde eğitim, sağlık ocağı, köy konağı ve dini tesisler mevcuttur [12].

Ücüncüsü; Karaman İli Merkez İlçesi'ne bağlı Madenşehri Köyü olup; köyün 2007 nüfusu 307 ve 2012 yılı nüfusu 292 kişidir. Köyün ile uzaklığı 35 km ve ilçeye uzaklığı 18 km’dir. Köyün temel 
geçim kaynakları tarım ve hayvancılıktır. Mevcut yerleşim yerinin tamamı ovada bulunmakta olup; köyde eğitim, dini, köy konağı tesisleri mevcuttur. Ancak mevcut köy yerleşimi sit alanı ilan edildiği için mevcut tesislerde tadilat ve eklemeler yapılamamaktadır. Bundan dolayı köy gelişme alanı tespit edilen alanda eğitim, kültür, dini, ticari, sağlık tesisleri ile köy konağı için yer ayrılması gereklidir [12].

\subsection{Konya İli Karatay İlçesi Katrancı Köyü İmar Planı Projesi ${ }^{\dagger}$}

Konya İli Karatay İlçesi Katrancı Köyü’nde nüfus projeksiyon hesabına göre köyde 20 yıl sonrası için 136 ailenin konut ihtiyacı olduğu tespit edilmiştir. Köyün mevcut ve gelecekteki sosyal, kültürel ve eğitim donatı ihtiyaçları göz önünde bulundurularak mevcut köy yerleşim yeri çeperinde köy gelişme alanı belirlenmiştir. Köy imar planı çalışmalarıyla köyde 122 adet konut parseli, sosyo-kültürel tesis, sağlık tesisi, eğitim tesisi, yönetim merkezi, ibadet alanı, köy konağı, kooperatif, ticaret tesisleri için yer ayrılmıştır. Böylece köy gelişme alanı çalışmalarıyla köyde hem genişlemenin planlı şekilde olması yönlendirilmiş hem de köyün mevcutta ve 20 yıl sonrası için ihtiyaç duyacağı sosyal tesis ve barınma ihtiyacının \% 90'ı karşılanmıştır. Katrancı Köyü'nde tespit edilen köy gelişme alanı ve hazırlanan imar planı paftaları aşağıda yer almaktadır.

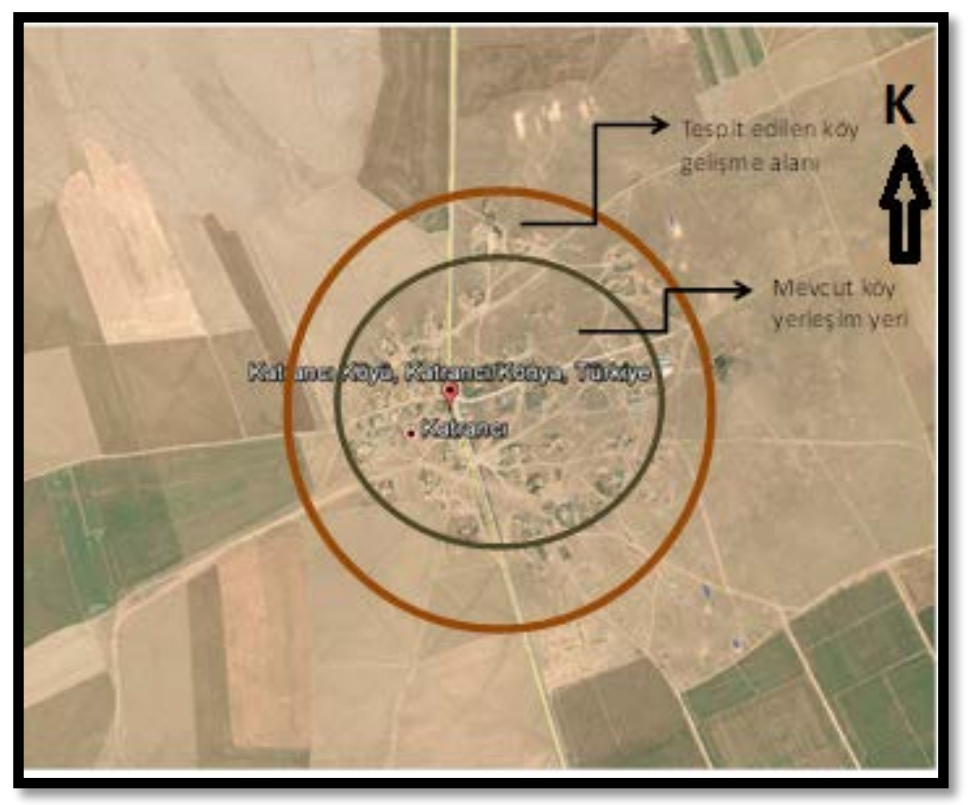

Şekil 3. Konya İli Karatay İlçesi Katrancı Köyü [11]

\footnotetext{
† Gıda Tarım ve Hayvancılık Bakanlığı Tarım Reformu Genel Müdürlüğü’nün 2013 yılı projesidir.
} 


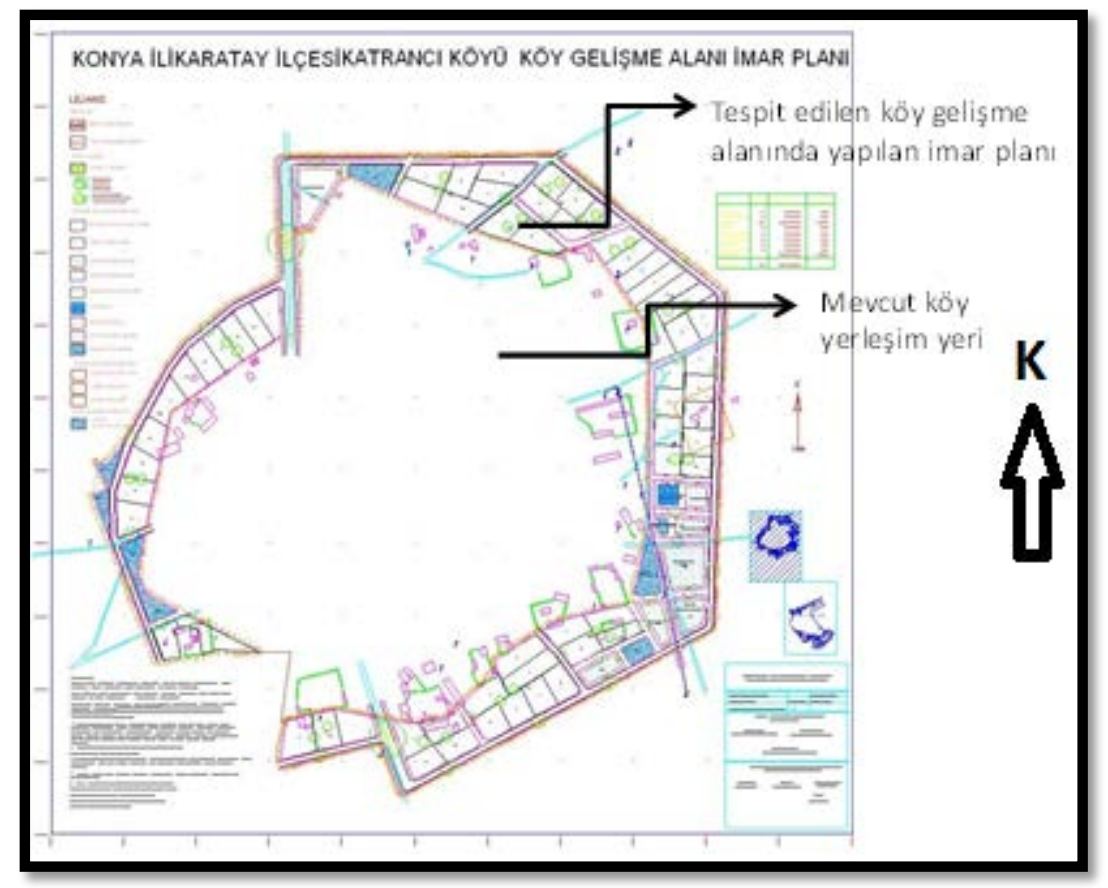

Şekil 4. Konya İli Karatay İlçesi Katrancı Köyü imar planı [12]

\subsection{Nevşehir İli Derinkuyu İlçesi Kuyulutatlar Köyü İmar Planı Projesi ${ }^{\ddagger}$}

Nevşehir İli Derinkuyu İlçesi Kuyulutatlar Köyü'nde köy gelişme alanı tespit çalışmalarında; 20 yıllık nüfus projeksiyon hesabı sonucu nüfusta azalış görülmekte, ancak muhtarla yapılan görüşmeler sonucunda mevsimsel yağışlara bağlı olarak köyde konutların sel baskınına maruz kaldığı, ayrıca köyde konut yapmak için yeterli alan olmadığından il dışında yaşayan ailelerin köye yerleşemediği anlaşılmış olup; bu nedenlerle köyde mevcut durumda konut ihtiyacı olduğu tespit edilerek mevcut köy yerleşim yerinin kuzeydoğusunda köy gelişme alanı belirlenmiştir. Böylece yapılaşmaya uygun olmayan mevcut köy yerleşimi dondurulmuş olup; köy sınırları içerisinde doğal afetler yönünden yerleşime daha uygun bir alana doğru yapılaşma yönlendirilmiştir. Kuyulutatlar Köyü’nde tespit edilen köy gelişme alanı aşağıda yer almaktadır.

\footnotetext{
‡ Gıda Tarım ve Hayvancılık Bakanlığı Tarım Reformu Genel Müdürlüğü’nün 2013 yılı projesidir.
} 


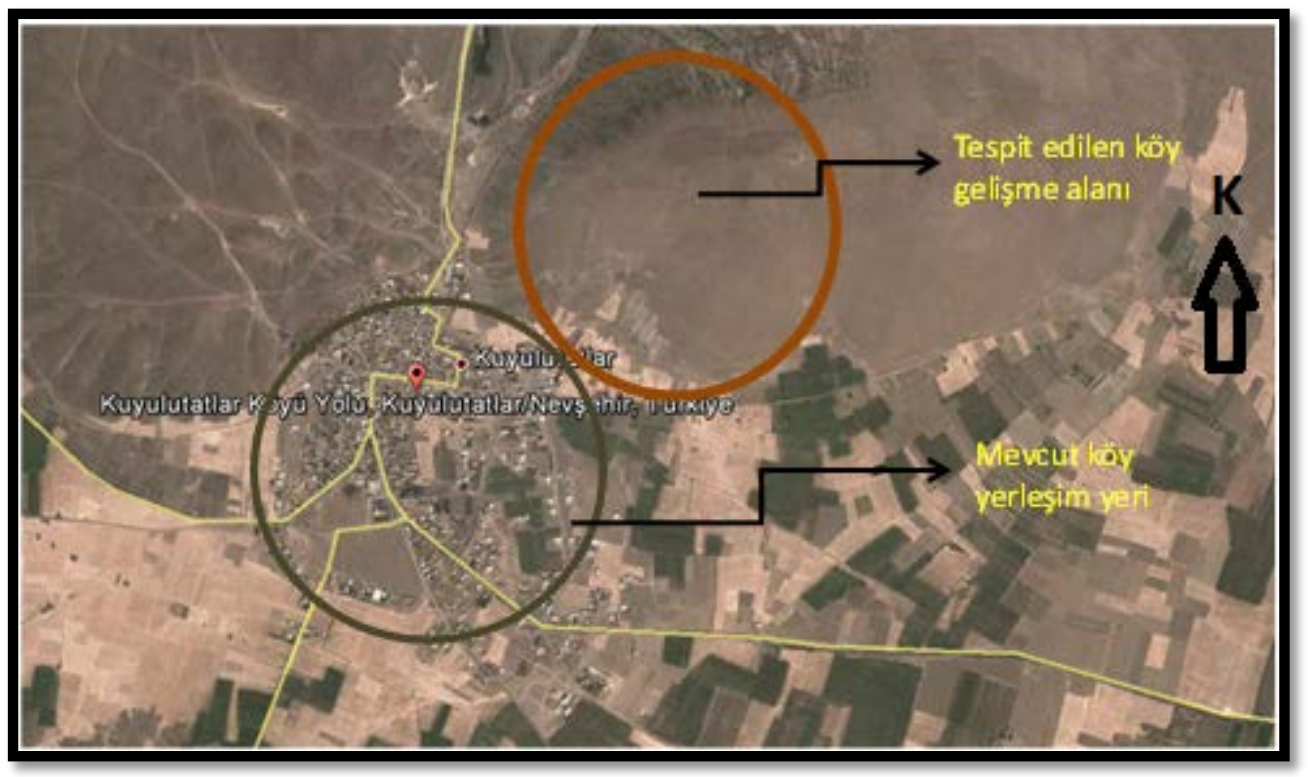

Şekil 5. Nevşehir İli Derinkuyu İlçesi Kuyulutatlar Köyü [11]

\subsection{Karaman İli Merkez İlçesi Madenşehri Köyü İmar Planı Projesi ${ }^{\S}$}

Karaman İli Merkez İlçesi Madenşehri Köyü’nde arazi toplulaştırma projesi kapsamında sit alanı ilan edilen mevcut köy yerleşimin mevcut ve gelecekteki konut ihtiyacının karşılanması için mevcut köy yerleşim yerinin kuzeyinde köy gelişme alanı belirlenmiştir. Köyde imar planı projesinin uygulanmasıyla köyde yaşanan konut arsası eksikliği karşılanmış olup; köyün ihtiyaç duyduğu tesisler ve konut alanı imar planı kapsamında arazi toplulaştırma projesiyle birlikte karşılanmıştır. Madenşehri Köyü’nde tespit edilen köy gelişme alanı ve hazırlanan imar planı ile arazi toplulaştırma projesi aşağıda yer almaktadır.

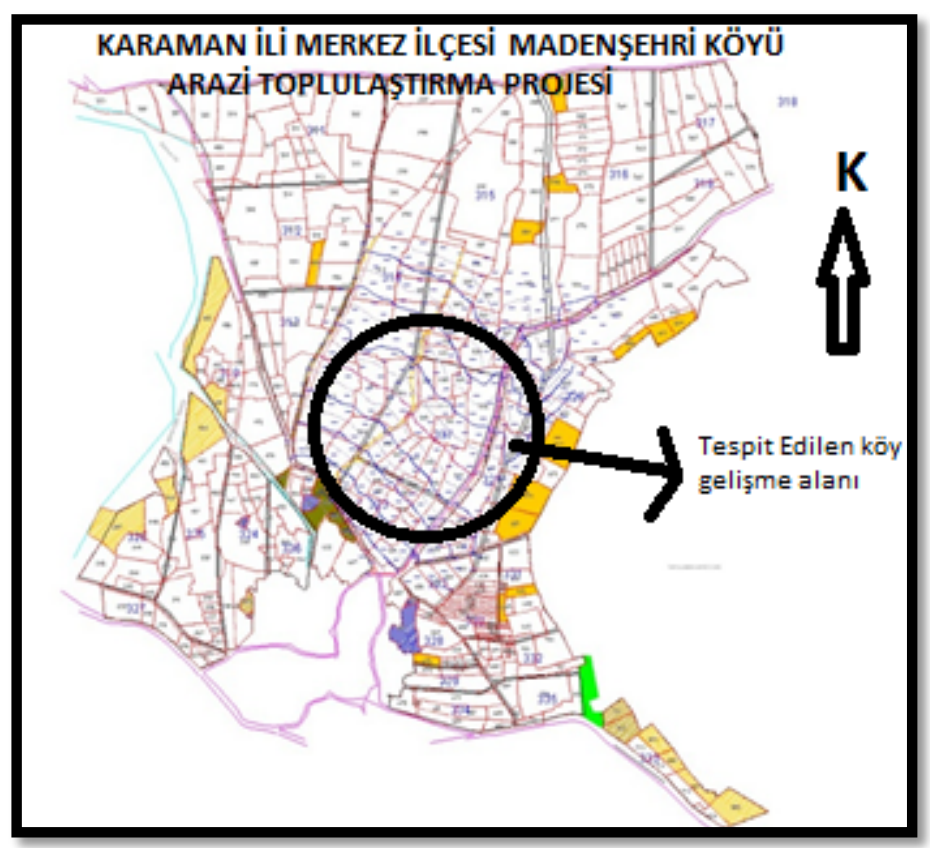

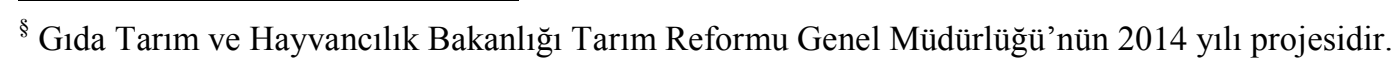


Şekil 6. Karaman İli Merkez İlçesi Madenşehri Köyü arazi toplulaştırma ve köy gelişme alanı projesi [12]

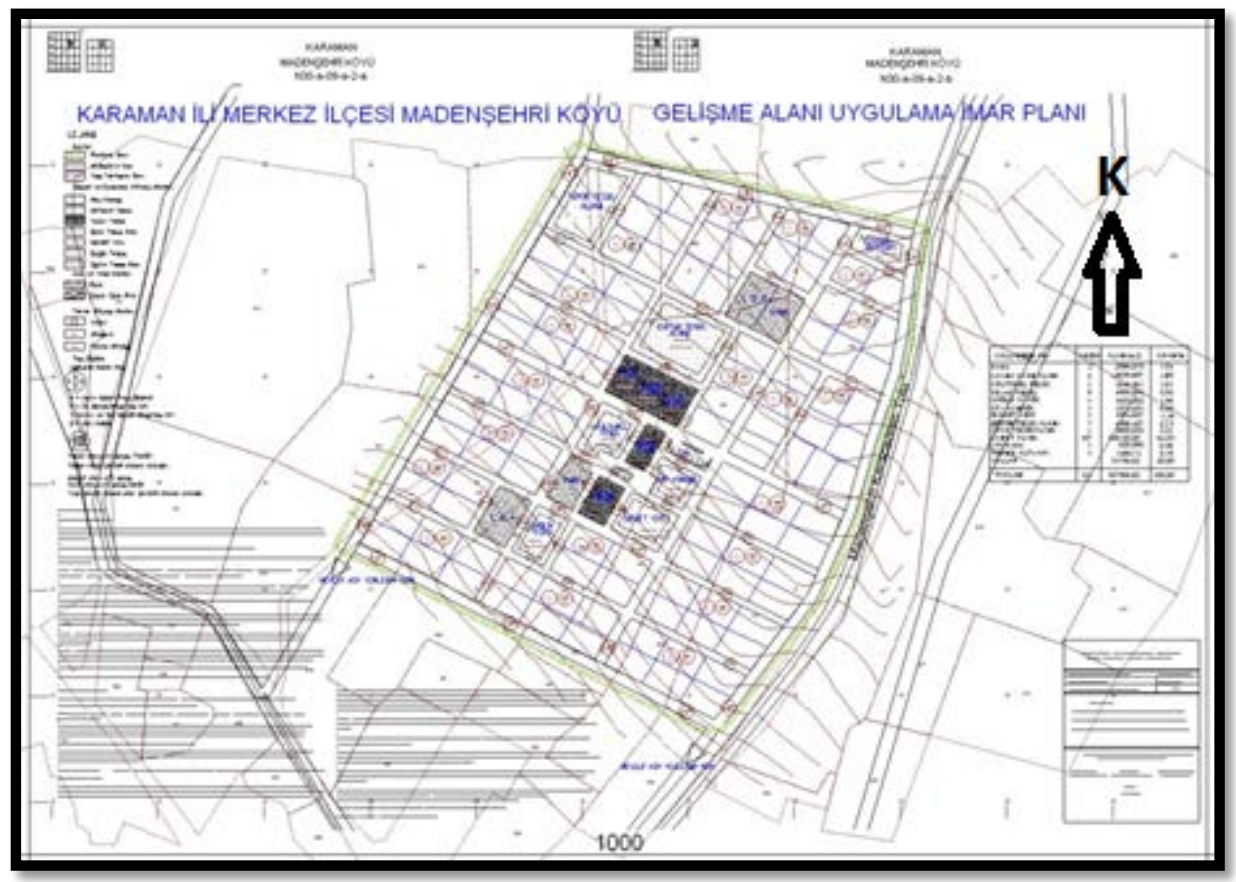

Şekil 7. Karaman İli Merkez İlçesi Madenşehri Köyü imar planı [12]

\section{Tartışma, Sonuç ve Öneriler}

Tarım arazilerinin tarım dışı kullanımını ele alan çalışmaların ortak noktası; "'tarım arazilerinin mevcut potansiyellerinde değerlendirilmesi, doğal kaynaklarının sürdürülebilir kullanımında temel esas olması"dır. Ülkemizde tarım arazilerinin en temel sorunları arasında erozyondan sonra en önemlisi tarım arazilerinin tarımsal amaçlar dışında kullanılmasıdır. İlk sorun olan erozyon sorunu doğal müdahalelerle azaltılırken, ikinci sorun olan tarım dışı kullanımı azaltmak için çok yönlü müdahaleye ihtiyaç duyulmaktadır. Literatürde çoğunlukla; arazi kullanım planlarının tamamlanması, mutlak korunacak tarım alanlarının belirlenmesi ve mevzuata dayalı önlemler ilk sırada yer almaktadır.

Tarım arazilerinin tarım dışı kullanım alanlarından birisi; çiftçilerin konut yapmasıdır. Çiftçiler kendi tarım arazilerine oturacağı konutu inşa etmekte veya devlete ait herhangi bir arazi üzerine ihtiyaç duyduğu konutu yapabilmektedir. Bu durum ise tarım arazilerinin zamanla yapılaşmaya açılması ve tarım yapılamaz hale gelmesiyle sonuçlanmaktadır. Konut alanlarının tarım alanlarına yapılması hem yapılaşma açıdan çok önemli sorunlara neden olmakta, hem de stratejik öneme sahip gıda üretiminin azalmasında önemli rol oynamaktadır.

Ülkemizdeki köy ve köy altı yerleşim birimlerinde konut ihtiyaçları çeşitli yollarla karşılanmaya çalışılmaktadır. Bu yöntemlerden bazısının sonuçları tarımsal nitelikli arazilerin yapılaşmaya açılması yoluyla kaybedilmesine ve plansız yerleşimlerin oluşmasına neden olmaktadır (Şekil 8). 


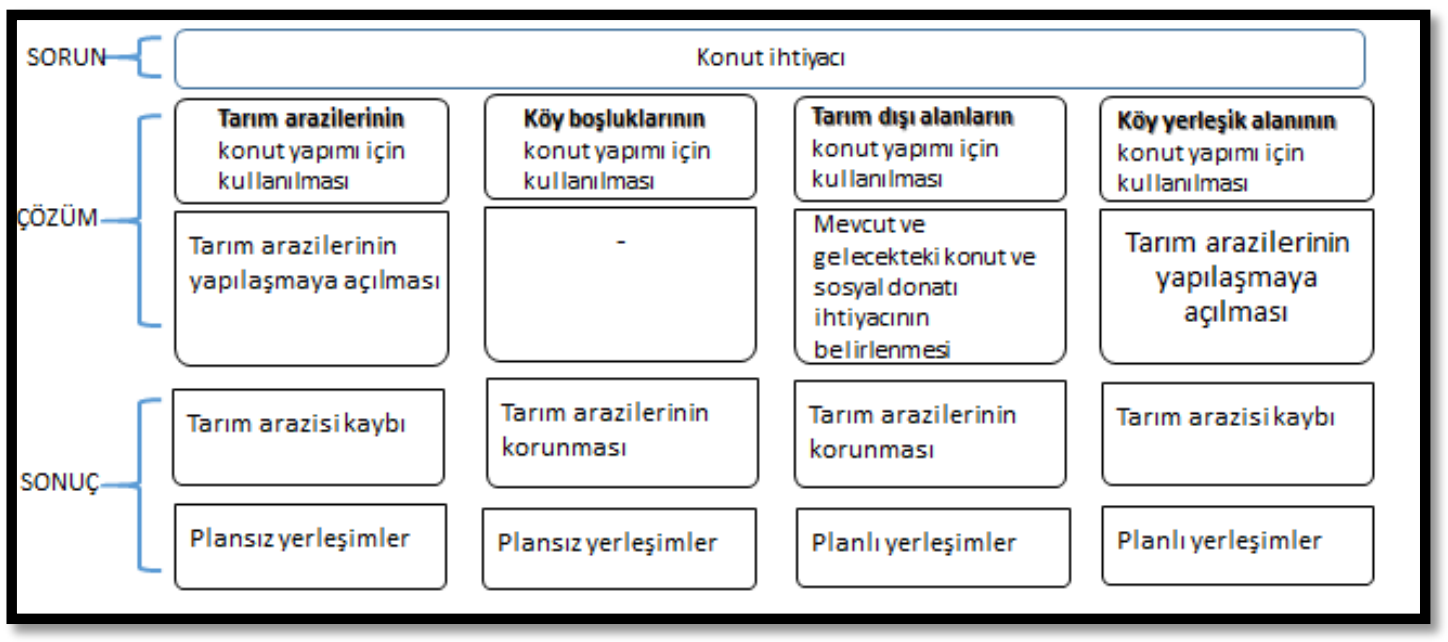

Şekil 8. Kırsal alanda konut ihtiyacı sorununun çözümü ve sonuçları

Kırsal alanda konut ihtiyacını çözmede ilk yöntem; çiftçinin kendi tarım arazisine konutunu yapmasıdır. Bu yöntemin tarım arazilerinin azalması ve plansız yerleşimlerin oluşması şeklinde hem çevresel hem de mekânsal olumsuz sonuçları bulunmaktadır.

Diğer yöntem; mevcut köy yerleşimindeki boşlukların konut yapımı için kullanılmasıdır. $\mathrm{Bu}$ yöntemde ise köy boşlukları konut ihtiyacını karşılamada yetersiz kalabilmekte hem de plansız yerleşimlerin oluşmasına neden olmaktadır. Buna karşın tarım arazilerinin yapılaşmaya açılması suretiyle arazi kayıplarını önlemekte ve tarım toprağını korumaktadır.

442 Sayılı Köy Kanunu ve Köy Yerleşim Alanı Uygulama Yönetmeliği'ne göre uygulanan köy yerleşik alanı yönteminde ise mevcut yerleşimin sınırından 100 m'lik bir çeper çizilmekte ve bu alan köy yerleşik alanı olarak tescil ettirilmektedir. Bu yöntemde ise $100 \mathrm{~m}$ 'lik alan içerisinde verimli tarım arazilerinin kalma ihtimali bulunmaktadır. Köy yerleşik alanı; bu yönüyle tarım arazilerinin kaybını tamamılla önleyememekte olup; planlı yerleşimlerin oluşmasına ise olanak tanımaktadır.

Kırsal alanda konut ihtiyacını çözmede kullanılan diğer yöntem ise 3083 Sayılı Sulama Alanlarında Arazi Düzenlenmesine Dair Tarım Reformu Kanunu ve 5403 Sayılı Toprak Koruma ve Arazi Kullanımı Kanunu'na göre uygulanan köy gelişme alanıdır. Bu yöntemde mevcut köyün bitişiğinde veya bütünlük teşkil edecek biçimde yakın olan tarım dışı maliye hazineleri üzerinde konut ihtiyacını çözmeye yönelik imar planı sonucu arsa üretilmektedir. Köy gelişme alanı uygulamaları sonucu tarım arazileri korunmakta ve planlı kırsal yerleşimler oluşmaktadır. Bu yöntem yalnızca maliye hazinelerinde uygulanabildiği için mevcut yerleşimin yakınında maliye hazinesi bulunmayan köylerde uygulanamamakta olup; bu yönüyle uygulanabilirliği kısıtlıdır.

Tarımsal niteliği olmayan arazilerden mevcut ve geleceğe yönelik projeksiyon hesabı yapılarak uygun büyüklükte tespit edilen köy gelişme alanlarında planlı bir yerleşim sunulmaktadır. Böylece yapılaşmanın olumsuz etkilerini önleme çalışmalarında bir yöntem olarak köy gelişme alanı uygulamalarının Türkiye genelinde yaygınlaştırılması, tarım arazilerinin iskan amacıyla olumsuz etkilenmesini azaltacaktır.

Köy gelişme alanı uygulamasının geliştirilerek ülke genelinde yaygınlaştırılmasıyla birtakım ulusal faydalar elde edilebilir. Bunlardan bazıları; 
- $\quad$ Bu uygulamanın yaygınlaştırılmasıyla tarım arazileri üzerindeki yapılaşma baskısının azaltılması ve planlı kırsal yerleşim birimlerinin oluşturulması, kırsal alandaki tarım arazilerinin korunması,

- Altyapısıyla birlikte tamamlanan köy gelişme alanlarının kırsaldaki insanlar için cazip yaşam alanı haline gelmesidir.

Köy gelişme alanı uygulamalarının artırılabilmesi için maliye hazinesi dışında kalan alanlarda da yapılması önemlidir. Bunun için uygulamayı yapan kurumca köy gelişme alanı olarak tespit edilen alanların gerekirse kamulaştırma yoluyla maliye arazisine dönüştürülmesi sağlanabilmelidir. Köy gelişme alanı uygulamalarının yalnızca imar planıyla kısıtlı kalmaması alt ve üst yapılarıyla tamamlanması, bu yöntemin kırsal alandaki insanlarca talep edilmesine yardımcı olabilir. Kırsal yerleşimlerin özgün yapı özelliklerinin korunabilmesi için ise; üretilen üst yapılarda yöresel mimari özelliklere dikkat edilmesi, yerel mirasın korunmasına da yardımcı olacaktır.

Tarım arazileri ile mekânsal kullanımlar arasındaki dengenin sağlanması, bu kaynakların sürdürülebilirliğinde önem taşımaktadır. Tarım arazilerinin etkin şekilde kullanılması ve korunması için; tarım dışı kullanımlar için kullanılabilir arazilerin belirlenmesi ve mutlak korunacak tarım arazilerinin tespit edilmesi işlemlerinin Türkiye genelinde tamamlanması gereklidir.

\section{Kaynaklar}

[1] Yılmaz, Ö., "Tarım alanlarının amaç dışı kullanımı ve Afyon örneği”, Afyon Kocatepe Üniversitesi Sosyal Bilimler Dergisi, 3 (1), 151-164, 2001

[2] T. C. Kalkınma Bakanlığı, "Tarım Arazilerinin Sürdürülebilir Kullanımı Çalışma Grubu Raporu”, Tarım Özel İhtisas Komisyonu, 96s, Ankara, 2014

[3] TUIK, 2010-2014 Yılları Tarım Verileri, Ankara

[4] Özbek, A. K. ve Öztaş, T., “Tarım arazilerinin amaç dışı kullanımı: Erzurum örneği”, Ekoloji Dergisi, 52, 1-6, 2004

[5] Özdemir, N., "Türkiye'de tarım bölgelerine göre toprak korumaya yönelik sorunlar ve öneriler”, Atatürk Üniversitesi Ziraat Fakültesi Dergisi, 26 (3), 460-473, 1995

[6] Topçu, P., "Tarım Arazilerinin Korunması ve Etkin Kullanılmasına Yönelik Politikalar", Uzmanlık Tezi, Kalkınma Bakanlı̆̆ İktisadi Sektörler ve Koordinasyon Genel Müdürlüğ̈̈ Yayınları, 145s, Ankara, 2012

[7] Kırzıoğlu, M. I., Yılmaz, H. ve Yılmaz S., "Ekolojik Temele Dayalı Kentleşme-Çevre Etkileşimi”, Atatürk Üniversitesi Ziraat Fakültesi Dergisi, 30 (2), 187-191, 1999

[8] DPT, "Ulusal Çevre Eylem Planı Arazi Kullanımı ve Kıyı Alanlarının Yönetimi”, Devlet Planlama Teşkilatı Yayınları, 94s, Ankara, 1997

[9] Uzun, B. ve Yomralıŏlu, T., "Doğu Karadeniz Bölgesinde Dağınık Yerleşim Sorunlarının Mülkiyet Açısından İrdelenmesi ve Kırsal Arazi Düzenleme Modeli”, Doğu Karadeniz Bölgesi Kalkınта Sетровуити 13-14 Ekim, 17s, Trabzon, 2005

[10] Aydoğdu, M., Tarini, M., Akçar H. T. ve Aydemir A., "Harran Ovasında Coğrafi Bilgi Sistemleri ve Uzaktan Algılama İle Tarım Arazilerinde Amaç Dışı Kullanımın Tespiti”, TMMOB Coğrafi Bilgi Sistemleri Kongresi 02-06 Kasım, 5s, İzmir, 2009 
Akci A., Demirel MK., Şen Becu H.

[11] Google Earth, 2014 Verileri

[12] T. C. Gıda, Tarım ve Hayvancılık Bakanlığı Tarım Reformu Genel Müdürlüğü, Arazi Toplulaştırma ve Tarla İçi Geliştirme Projesi ve Köy İmar Planları Projesi 2011, 2013 ve 2014 Y1lı Verileri, Ankara 